ground, but without any of the unpleasant feelings associated with the word giddiness.

In people who are particularly susceptible, vertigo accompanied even by nausea and vomiting may easily be brought about by kinæsthetic impulses or by moving visual stimuli. But that the labyrinth is by far the most usual and important sense organ from which vertigo is aroused, and probably the only one concerned in sea-sickness, is now firmly established. James, Kreidl and Myginol have all commented on the immunity from sea-sickness of deafmutes in whom the labyrinths were deficient. The experiments of Dreyfuss on guinea-pigs and of
Kreidl on dogs, cats and pigeons pointed in the same direction. Decerebration, decerebellation, or section of both vagi leaves sea-sickness unaffected, but removal of both labyrinths or section of both eighth nerves results in complete immunity. The most likely explanation of the vomiting seems to be that it is caused by spread of excitation from the vestibular nuclei to the neighbouring medullary 'vomiting centre'.

As a result of the interest aroused in the discussion, a joint research committee of the Sections of Physiology and Psychology has been set up to investigate the conditions of vertigo and its relation to dis. orientation.

\title{
Fishes of Mountain Streams
}

$\mathrm{D}^{\mathrm{R}}$ R. SUNDER LAL HORA, of the Zoological Survey of India, has for many years devoted special attention to the study of the fauna of rapidly running waters in the hill streams of India. His knowledge of this difficult and interesting branch of zoology is unrivalled. No one, therefore, could be better qualified than he to undertake a detailed investigation* of that remarkable group of cyprinoid fishes, the Homalopteridæ. These fishes, inhabitants of swiftly running mountain streams of southern Asia, have undergone a great variety of adaptive modifications induced by the peculiar environmental conditions typical of their habitat.

In the first part of his report the author deals with the taxonomy of the group. It is divided into 2 sub-families-the Homalopterinæ, comprising 6 genera and 31 species, and the Gastromyzoninæ which is represented by 11 genera having in all about 16 species. In the Homalopterinæ 4 new species belonging to the genera Homaloptera and Lepturichthys, and 2 new varieties of Balitora brucei are described. Among the Gastromyzoninæ no new species have been found; but in order properly to classify the existing species 5 new genera are proposed in this paper. No attempt has been made to describe in full each and every species, but wherever an amplification of the already existing description seemed to the author to be desirable the species is

* Memoirs of the Indian Museum, vol. 12, No. 2, pp. 263-330. "Classifleation, Bionomics and Evolution of Homalopterid Fishes". By Sunder Lal Hora. Calcutta ; December, 1932. either redescribed or a note is inserted concerning some of its most important features.

In the second part of the paper the bionomies and evolution of the Homalopteridæ are discussed at some length. The most characteristic features of its members such as flattened shape, insertion of the pectoral fins (which are used for adhesion) far forward below or even in front of the eyes, possession of a peculiar rostral groove in front of and continued along each side of the mouth, the peculiar structure of the hard and strong lower jaw, are shown to be definitely correlated with the three most important factors in the environment-strong current, high oxygen content, and nature of the food supply available. Throughout the paper attention is repeatedly directed to the 'communal convergence' that is exhibited by these fishes and to the series of characters showing parallel development in the members of the two sub-families. From all the evidence which he has acquired the author believes that the Homalopteridæ are probably a polyphyletic family the members of which are derived from the Cyprinidæe and Cobitidæ and have come to resemble one another superficially under the influence of the same environmental conditions.

Dr. Hora is to be congratulated on having produced a paper which is not only a valuable addition to the literature on the taxonomy of the Homalopteridæ but is also of great theoretical interest.

G. A. S.

\section{Geological Reconnaissance by Aeroplane in Australia*}

$I^{\mathrm{N}}$ 1932 the Royal Australian Air Force made flights over many of those areas in Australia which are deemed to be worthy of investigation from the point of view of the discovery of oil. Dr. W. G. Woolnough, who was present as observer and geologist, has now detailed the results obtained in a report which gives valuable information regarding the function and importance of aerial work in assisting and expediting geological survey. The object was to determine the disposition of strata and especially to locate dome structures, the investigation being made partly by visual observation and partly by the study of the photographs taken from the air. Much experience is required before the utmost can be achieved by these methods, and Dr. Woolnough states that he scarcely began to appreciate the significance of details seen from above until he had completed one hundred hours of flying.

* Commonwealth of Australia. Report on Aerial Survey Operations In Australia during 1932. By Dr. W. G. Woolnough. (Canberra: Government Printers.)
From July until September, a circuit of Australia was made-also a visit to Tasmania, atmospheric conditions on the whole being favourable. Over Melville Island observation was hindered by a tribal fight, as part of the strategy consisted in the lighting of extensive bush fires, the smoke of which provided nuclei for the condensation of moisture and the development of clouds. The orientation of the photographs and the elevation of hills and scarps above the surrounding country can be determined by noting the direction and lengths of shadowsprovided the time of exposure is accurately known.

In those regions where the rocks are well exposed and where topographical forms are the direct result of the differential erosion of beds, the main tectonic features are easily seen, and examination of the photographs reveals where the detailed ground investigation which is essential to the full elucidation of the structure should be undertaken. Most valuable is the clearness with which the true disposition and 
continuity of strata can be made out from the bird's-eye view of country in which the ground worker is baffled at close quarters by the confusion of detail resulting from erosion, accumulations of detritus, and the presence of false dips due to local and superficial collapse of strata. The observer is warned against reading 'strike' into a banding due to the parallel alignment of superficial sand dune accumulations; furthermore, where dips are slight, it is often impossible to determine in which of the two possible directions they lie, and for this groundlevelling is required.

It was in bare featureless plains devoid of rock exposures that the most remarkable results were obtained. Sometimes it was possible to detect geological structures of great importance where the absence of outcrops presents an insurmountable obstacle to ground survey. Here a pattern can be discerned which the geologist can recognise at once as that of a geological map, and in one case the proved structure of an area with abundant outcrops was followed into adjacent lowlands the geological structure of which has hitherto remained hidden. Such pattern is due to the different appearances of soils to the 'actinic eye' of the camera. Clearly these soils have developed from the weathering of the rocks beneath them, the disposition of which they thus reveal. Pattern may be seen through thin parched grass but it is lost with a fresh luxuriant growth, and the survey must be made when the conditions are favourable.

Some success was achieved in gleaning information regarding the geology of heavily forested regions, and much may be expected from the further development of this line of attack on a type of country which is the despair of the investigator on the ground.

L. H.

\section{University and Educational Intelligence}

LONDON.-The following appointments to University readerships have recently been made : botany (Birkbeck College), Dr. F. C. Steward, since 1929 assistant lecturer in botany in the University of Leeds; epidemiology and vital statistics (London School of Hygiene and Tropical Medicine), Dr. A. B. Hill, who since 1923 has been carrying out investigations and research at the School.

The title of emeritus professor of eugenics in the University has been conferred on Prof. Karl Pearson, on his retirement from the Galton chair of eugenics at University College, and that of emeritus professor of Egyptology in the University on Sir Flinders Petrie, on his retirement from the Edwards chair of Egyptology at University College.

The following degrees have been awarded: D.Sc. to B. F. Barnes (Birkbeck College) for ten published works on botany; D.Sc. to J. C. F. Hopkins (King's College) for ten published works on plant pathology.

Mr. Thurkill Cooke, a member of the General Committee of the British Association, has offered to present to the universities of England a collection of works on nautical science. The first presentation under the offer has been made to the University of London. Librarians of English universities desirous of receiving such accessions should communicate with the Assistant Librarian, British Library of Political Science, Houghton Street, W.C.2.

\section{Science News a Century Ago}

\section{Royal Society, January 9}

The portrait of the late president, Davies Gilbert, painted by Thomas Phillips, R.A., at the solicitation of several members, was, by their request, presented to the Society. A paper was read on 'The Empirical Laws of the Tides in the Port of London'. By the Rev. William Whewell, F.R.S., Trinity College, Cambridge. The author regards existing tide tables as extremely imperfect; the mathematical solutions of the problem founded on hypotheses remote from the real facts. The Earl of Tyrconnel was elected into the Society.

\section{The Royal Medals of the Royal Society}

The January issue of the Gentleman's Magazine in 1834 contained an excellent notice of the anniversary meeting of the Royal Society. The Duke of Sussex made a statement relative to the Royal medals placed at the disposal of the Society by His late Majesty in 1828. Mr. Chantrey, in conjunction with Sir Thomas Lawrence, was appointed to prepare a design. Either from indecision, or that procrastination for which the late president of the Royal Academy was characterised, the design was never furnished, although it was a frequent and favourite theme of conversation. After an inquiry, steps were taken, however, to redeem all the pledges made by George IV to the Royal Society. The Gentleman's Magazine records the awards of ten medals to the following, and the reasons: Dr. Dalton, to whom was owing the development of the atomic theory; although at the eleventh hour, it was gratifying to know that he was acknowledged as its author both at home and abroad; to Mr. Ivory, the first English philosopher who introduced to Great Britain the beautiful and refined discoveries of Laplace, Lagrange and other foreign astronomers; to Sir Humphry Davy and Dr. Wollaston in testimony of services in science; to Prof. Struve, for researches respecting double stars; and to Prof. Encke, the greatest, perhaps, of modern astronomical calculators, and the discoverer of the comet which bears his name. The Duke of Sussex alluded to Sir John Herschel as one who had terminated his European labours; and a rich harvest was to be expected as the result of his labours in the ample field of a new and unexplored heaven.

\section{The Mechanics' Magazine}

The issue of the Mechanics' Magazine for January 4, 1834 opens with a reprint of a paper by Dr. Robert Hare, then professor of chemistry in the University of Philadelphia, on a galvanic rock-blasting apparatus, in which the use of electricity is advocated for mining. This is followed by a reprint of a paper by Mr. Sang, of Edinburgh, on the relation of a machine to its model. Next there is correspondence on canal improvements, and on the performances of the steam carriages of Hancock and Maceroni, followed by a note on isometric projection and a letter from John Ericsson on his caloric engine. Of considerable interest are the notices of the activities of two societies. The Marylebone Literary and Philosophical Society, it was stated, was in a very flourishing condition and had bought 17 Edwards Street, Portman Square, where it was proposed to erect a lecture 